\title{
5: $131854326-131846679$
}

National Cancer Institute

\section{Source}

National Cancer Institute. 5:131854326-131846679. NCI Thesaurus. Code C45116.

Physical location of IRF1_Gene 